\title{
The Influence of Religious Values on the Development and Functioning of Economic Institutions
}

Konstantin Victorovich Vodenko

\author{
Svetlana Alexandrovna Tikhonovskova
}

Platov South-Russian State Polytechnic University (NPI)

Email: vodenko-kv@rambler.ru; tihonovskovas@yandex.ru

Doi:10.5901/mjss.2015.v6n3s4p45

\begin{abstract}
The article devoted to the analysis of interaction and interference of socio-economic institutes and Christianity. In the article is considered historical and sociological tradition of learning religion and economy (M. Weber and others). Based on works of Russian speculators (N.A. Berdyaev, S.N. Bulgakov, V.I. Ilyin, V.C. Soloviev and others) are considered problems of labor, property, assignment, specificity of economic activities in the light of the official doctrines of the Christian churches. Concludes that the introduction of the Christian principles of management dictated by the course of the global development of a modern economy. Moreover, then the artificial nature created by the person becomes for the Universe a foreign matter and as the foreign matter is eliminated together with his local creators. To leave this deadly position, S. N. Bulgakov writes, the humanity should realize, at last, that the world is dual: it is spiritual and material at the same time. Production, as well as all the activity, society has to merge both with spiritual, and with material structure and evolution of the world.
\end{abstract}

Keywords: social institute, economics, religion, Christianity, labor, property.

\section{Introduction}

As is known, that the main key the methodological-theoretic principle of modern sociology allows disclosing the features of development of religion and its influence on society is the theory of social institutes, developed in the context of the structurally functional analysis and neo-institutionalism. The American structural functionalism on behalf of $\mathrm{T}$. Parsons and R. Merton (Parsons, 2000, became a crucial stage of the history of functionalistic representations in the sociology of religion \& Merton, 2006). In modern conditions of search of new models of social and economic development, the problem of specifics of the interaction of institute of religion and economic, social institutes is updated. On this question turned the attention to classics of social philosophy and sociology (M. Weber, V.L. Brentano, V. Zombart, etc.). Among foreign concepts of a ratio of religion and economy, we will stop at $\mathrm{M}$. Weber's works, devoted to the cultural value of capitalism. Work "Protestant ethics and spirit of capitalism" (Weber, 1990) in two parts and (Weber, 1994) articles collected in "Economic ethics of world religions" together with the corresponding chapter in "Economy and Society" were integrated by I. Winkelman under the general heading "Religion Sociology".

The main attention of M. Weber in "Protestant ethics" and other works on economic ethics was directed at studying of cultural value of modern capitalism that he was interested in capitalism not as an economic system or result of class interests of the bourgeoisie, and capitalism as daily practice, as methodical and rational behavior. According to M. Weber, industrial practice as a line of the cultural life of society testifies to value and impact of religion on its development and forming. Protestant ethics, especially its ascetic version, made a considerable contribution to a cultural basis of modern capitalism. Its lines played the unique role as an ideal of professional work and "inner-asceticism" (an opposite "out of asceticism", for example, Buddhist monks), that is the obligation of a modest way of life in combination with vigorous activity in the world and tireless work. Thus, the individual bore responsibility only for himself and the belief. A consequence of these properties of ascetic Protestantism, or Puritanism, was that all life, and not just its religious and church sphere was based on ethical behavior. The person became "the profitable car of God", and work turned into an end in itself. Evolved from Protestant ethics not only modern entrepreneurship with its capitalist calculation, but also the operation of workers for belief and indifference to poverty that as was considered, was the result of an own fault.

The incentives originating in the religion continued to exist even after religious impulses disappeared. The belief disappeared, and the methodical and rational form of behavior remained. M. Weber considered modern to him capitalism not as based on religion at all and saw in it more likely "an empty shell" which without spiritual filling was close to a 
mechanical petrifaction. M. Weber's instructions are remarkable that Jews could not lay the foundation of that religious and cultural position that became initial for modern capitalism, and even were opposite it like in the field of economy they are the speculator, but not the rational specialist.

In "Economic ethics of world religions" M. Weber investigated the impact of religions on practical behavior, first of all economic behavior; thus, also communications between religious ideas and social groups were considered. Religious was for it "out of - the everyday"; at least, former cults and religious beliefs consciously and intentionally are located out of a daily context of life. However, if they extend and cover a large number of believers, become 'churches' or sects, they to a certain degree should become more secular again.

\section{Investigations and Methodologies}

Great world religions as a rule were developed from the magic and ritual beginnings in "rational" doctrines and system of the church. However, sometimes process proceeded on the contrary: from spiritualistic-intellectual ideas to mass magic and ritual cults (Buddhism). If the Judaism, Islam (which Weber does not consider), Puritanism and Confucianism can be considered as religions suitable for worldly life, for the Buddhism, Jainism, a Lamaism and early Christianity typically negative relation to the world. Only Puritanism could break stereotypes and the traditional relation which were inherent to religions in their relation to economic and practical life and even to influence them updating.

M. Weber investigated a question, what layers originally were carriers of great world religions. So, peasants were never carriers not - magic cults, but also predecessors of "bourgeoisie", merchant and trade layers, also always had an addiction to "sidedness" religions with pronounced magic lines. A particular case is Confucianism, as "religion of officials" as officials, as a rule, do not belong to the leading religious groups. The nobility was also rare the carrier of religious ideas, except as in connection with its role in the formation of a community or religious wars (Islam, Sikhs, Buddhist monks-soldiers, crusaders). The Christianity typical religion of handicraftsmen and the city phenomenon was more ancient that is the consanguinity and clans did not play an important role. Thus, if the rural handicraftsmen remaining within some (for example, in India) had a tendency to magic and ritual religiousness, city handicraftsmen were carriers of rational religiousness. The difference consists also that religions of high layers in general legitimated the existing life device while religions of the lower class promised the best lot in the world terrestrial or the world other, rescue, and sometimes and vengeance in the next world.

The designated historical and sociological tradition of analysis of relationship between economy and religion was continued in works of domestic religious thinkers (L.P. Karsavin, N. A. Berdyaev, S. N. Bulgakov, V. I. Ilyin, V. S. Solovyov, etc.) at research of such concepts as "progress", "benefit", "work", when studying influence of religion on relations of production in society. The main ideas of the Russian religious thinkers about the influence of Christianity on the development of social and economic institutes formed "The basis of the social concept of Russian Orthodox Church".

The progress of society is saturated with contradictions. In moral aspect in it two poles - the good and evil are continuous. All history of a civilization is the history of the fight of classes, the people, and the states. In this battle, that sometimes hidden or open, overcomes the evil in a result. Such course of history was inevitable, both bourgeois economists, and founders of the scientific communism claim. So hundreds of millions people for the millennia were sacrificed progress, in the victim to that "bright future" which tempting contours for centuries soared in the inflamed imagination of progressive secular thinkers which ideal design and remained the ghost departure for the historical horizon. Therefore, instead of fantastic El Dorado from a flame of civil and international wars came up only societies with new forms of operation and social oppression. So public progress performed due to disasters of a people at large naturally generated fascism - ideology and practice of enslavement of the people the nations standing on the advanced boundaries of scientific and technical progress.

The Christianity opposed to the economic concept of secular society the economic theory. Its essence makes not progress (scientific and technical, economic, any other), and the benefit, good. The benefit is the growth of spiritual and material wealth of each person, each class, each nation, improvement of quality of life of all people, and not just stood apart from the people of social elite. Achievement of the benefit, undoubtedly, assumes growth of intelligence, improvement of a method of production, but not as end in itself, and as an instrument for ensuring of a universal peace and well-being, general prosperity and happiness. It is a priority for the benefit - not intelligence, but ethics. Ethics space, social and personal.

Having left primitive society in which communistic regulations of life dictated living conditions, the humankind created a perfect economy based on labor division and began the fast accumulation of riches. The distinction of people on intelligence and a kind of activity, managerial and primarily work executive should not have given division of work into work, on Christian canons, to property stratification of people. Had to use the benefits of progress all. Virtue blessed 
Augustine wrote, "Does not dress up in purple togas, does not shine with luxury, and wears a raincoat of the beggar". Material welfare, freedom and equality of people irrespective of the fact, which they take a place in production hierarchy, would provide true honor to leaders of the people, the maximum labor activity of each person, outstanding cost efficiency of a social production. However, religious virtues were roughly trampled by the breeding top, which stood apart from the people. There was a stratification of society into antagonistic classes. In addition, it started being shaken antagonism. Slaves were not interested in the development of economy, broke instruments of labor, and sometimes rose. Massive forces and means were distracted from socially useful work, thrown for implementation, not of the creative purposes. Feudal and capitalist societies only increased scales and sharpness of antagonism. In the wars replacing each other the most productive labor power perished, enormous material values were exterminated. Not for the purpose of creation and for the purpose of destruction also the best achievements of scientific and technical progress were often used.

This radical defect is inherent also in modern society. Significant growth in material wealth was followed in the XX century by the growth of cruelty, crime, debauchery, in spirituality unknown earlier. Life once again confirmed the validity of words of the apostle Pavel: "Wisdom of this world is madness before God" (1 Box. 3: 19). N. A. Berdyaev wrote: "The terrestrial spirit of the mankind which went on the way of a serpent hypnotized the person tempting idea of progress and the earthly paradise approaching at the end of growth, and the person that did not notice madness of the service to development and the subordination of lucky individuals of the future paradise was so seduced. Progress blossoms on a cemetery and all culture of the improved mankind are poisoned with ptomaine" (Berdyaev, 1989, p. 123). Modern production, "Bases of the social concept of Russian Orthodox Church" state, "promotes the improvement of material living conditions of the person. However, seduction by achievements of a civilization deletes people from the Creator, conducts to the imaginary celebration of mind aiming to equip terrestrial life without God. Implementation of similar aspirations in the history of humanity always ended tragically.

In the Scripture (Bible) it is told that Cain's descendants were the first builders of a terrestrial civilization: Lamech and his children invented and made the first tools from copper and iron, figurative tents, and different musical instruments, they were ancestors of many crafts and arts (Genesis. 4: 20-22). However, they together with other people did not avoid temptations. "Any flesh perverted the way on the earth" (Genesis. 6: 12), and therefore at the will of the Creator the civilization of Kainite's is completed by a flood".

Work as the benefit, as a virtue has, according to the social doctrine of Christianity, three main aspects.

Work first is urged to be an essential part of space evolution. "From the Christian point of view, - emphasize Bases of the social concept of the Russian Orthodox Church (ROC), - work in itself is not unconditional value. It becomes blessed when is co-working to the Lord and promotes the execution of his intention to the world and the person". Work that makes society richer, but destroys nature - this is the cosmic evil. Therefore conducts humanity to death. Also dreams of a blissful life without effort, about the fantastic earth where the dairy rivers in a land of milk and honey, about paradise in which boundless idleness reigns flow, are so harmful. Space trade does not suffer "parasitism", it eliminates useless from the foreordained evolution of the Universe. Real meaning of the life of the person noted I.A llyin, that consists "In work over creation of the God's Kingdom", in work in which the person comprehends all greatness and beauty of the world and starts feeling the tool of the highest forces" (llyin, 1993, p. 317, 320). Such religious concept of work is inherently incompatible with the bourgeois concept of the civil society, which turned the person into the center of the universe, and his egoism - in a basis of all social and economic system.

The person rejected this celestial concept of work. Instead of the creativity to enter objective evolution of the nature, it began its "conquest" and injurious consumption. The business case of consumer society with its market regulator extended by the West worldwide. Only having replaced model of the economy based on uncontrollably growing consumption of natural factors with the essentially new model, has been included it in "universal fabric", the humanity will provide the future.

Work secondly is urged to become a basis of truly humane society. Reminding this common truth, the church emphasizes: interaction of people in the course of work has to be based not on egoism and mercantilism, as now, and on virtue, on care of the general benefit and disinterested mutual assistance. The religion estimates each person, each class, each nation in social aspect not so much of their contribution to creation of real wealth, how many on, whether they not in words, and in practice provide an achievement of peace and a consent, the society, material prosperity, safety and confidence in the future to each person. The abundance of goods at the poverty of considerable part of the population and subjects is more at its extinction, there is not a benefit, but the evil. Neither self-interest nor national egoism, but sincere goodwill and mutual assistance has to dominate the international scene. Church learns that merge of interests of the nations cannot occur on purely economic basis - it demands their preliminary moral, world outlook, religious consolidation.

The statement of public virtue has the second side - fight against the evil, initiative, competent and consecutive. 
The egoism and mercantilism deprived of moral bases inevitably generate corruption, organized crime, the aspiration to eliminate the competitor for what any methods are sometimes used, up to custom-made murder. Nonresistance to the evil is justified only in the field of private life, learns church. In society, it would mean de facto clearing of an area for an evil celebration. It is necessary to remember also that in the economy, as well as in other areas of public life, angrily, as a rule, it puts on make-up under good. "Round lust of a profit, round self-sufficing love to money, - N. A. Berdyaev notes, one of the most phantasmagoric is created (i.e. elusive - a bus) the worlds, that are torn most off from the world of reality from life. Such phantasmagoric world is the world of capitalism, the world of banks, the exchanges, paper money, checks and bills of exchange, advertising, the competition and a pursuit of easy money. This fantastic world lives under the law and did not interested in to know the Scripture, is creation of human lust, egocentric passions in which the person loses freedom and the God's image" (Berdyaev, 1993, p. 162). The huge octopus who accepted the global sizes closed by a trade secret serves only those who has the capital; that is a small minority of the population.

In dialectics of the good and evil, the church allocates one more aspect. "Against God, - N. A. Berdyaev writes, Rebelled doesn't only the evil, but also kindly, incapable to conciliate with the fact of the existence of the evil. The atheism has the roots not only in the evil, but also in good" (Berdyaev, 1993, p. 37-38). When life becomes intolerable, at large people often rises and starts destroying agents of the social evil. However, private interests still are predetermined by the behavior of each person; a victory oppressed over oppressors of anything in principle does not change. Social poles are only interchanged the position. The paradox is that the oppressed will never prevail because, in the moment of victory, they become oppressors. "Moreover, therefore no external revolutions in the provision of people correspond to the radicalism of the revolution announced by the Gospel ... The morals of the God's Kingdom are not similar to morals of the world fallen, being on each side of the good and evil" (Berdyaev, 1993, p.105).

Work thirdly is urged to become a basis for forming of the new person. The person who consciously joined in space evolution as its creative element. The person is capable to create real free and happy society.

The social qualities, we will remind, the person acquires knowledge by social inheritance. "... In private life all its valid contents turns out through the public environment and anyhow is caused by this state, - V. S. Solovyov wrote. - In this sense, it is possible to tell that society is the added or expanded personality, and the personality - squeezed or concentrated, society" (Solovyov, 1988, p. 285-286). So the society which wallowed in defects created everyone entering into it since the birth just like the. Moreover, the person who is brought up sinful established and strengthened, in turn, vicious society.

To get out of this deadly circle, the religion learns, the person has to join qualitatively higher - church community in which it will find examples of other behavior, samples of a brotherhood, love and virtue. To the society founded on Avidity and lust, the person has to oppose the moderate consumer asceticism, which is lit up by the growing spiritual wealth. In each person, huge energy is concentrated. Placed at service to individual, class and national egoism, it eventually conducts to death and the person, and all society. Voluntary placed at service to people and objectively included in the evolution of the world, it provides the original progress of humanity, happiness, safety and immortality of the personality. One of these ways the person chooses himself.

Such is a basis of the religious concept of work. Secular society rejected it. Therefore, it was implemented, in that measure in what it was possible to be made, in religious, economic communities.

Relations of production are; I will remind, the relations that objectively develop between people in the course of joint work. In their structure, the science usually allocates as the primary relations of property, the relation of an exchange of activity and the distribution relations. What their religious interpretation and what impact the church has on their forming and evolution?

The property is free (fixed in the state right) ownership, use and the order of spiritual and material production factors. Property, V. S. Solovyov notes, is concluded in the being of the human person. It includes first of all me: my thoughts and emotions that I can transmit or not give another; my body of which without my voluntary consent nobody has the right to dispose. The Christianity initially opposed the transformation of the person into the property of other person, resolutely condemned slavery. Complete the happiness will be possible only in that life, Augustine wrote, "Where anybody will not be a slave any more". Nobelium of the slaveholding Roman Empire, the business considering murder of the slave natural and legal, the Christianity declared: do not kill, because the slave - the same image and God's similarity, as well as you. Also do not exhaust him with back-breaking toil: "Six days work and do any your things, and day of the seventh - Saturday - to the Lord, your God: do not do it any things neither you, nor your son, neither your daughter, nor your slave, neither your slave, nor your cattle, the newcomer, which in your dwellings: because in six days the Lord created the sky and the earth, the sea and everything that in them, and in day of the seventh rested." (Exodus 20: 9-11).

Proclaiming at the beginning of our era divine right of every person to liberty, the Church sought to introduce it 
everywhere in life. Moreover, sometimes made enough significant progress. The Russian Orthodox Church in the X-XIII centuries made in the Russian society "such resolute change which one was enough to make for church room among the main forces creating our society". The church, first, entered into the customs regulation of the charitable release of slaves according to the will. The church, secondly, established three cases of obligatory issue of the slave (lackey) on freedom: 1) The slave, begot children from own master, to his death he was surely released together with the begot children. 2) The free person who made violence over others uniform thereby did him free. 3) Slave or Servant who has suffered injury through the fault of their master became free.

The property of the person on the body and intelligence finds the natural continuation of its things, in property of the person on the tools which are switched on in its work, raw materials, materials and other means. The modern social concept of Russian Orthodox Church says: "The Church recognizes the existence of diverse patterns of ownership. The state, public, corporate, private and mixed patterns of ownership in the different countries received different rooting during historical development. The church does not give preference of any of these forms". The social doctrine of Catholicism accepted on the Second Vatican cathedral, provides: "The property and other forms of a personal authority over the external benefits promote expression of the personality, giving it the chance to show the responsibility in society and economy ... The private property or some power over the external benefits provides everyone the sphere of a necessary personal and family autonomy. They should be considered as manifestation of human freedom ... Forms of such power or property are nowadays different, and their variety does not cease to extend ..." (Casanova, 1973, p. 330). Vatican recognizes that "the state can have property on tools and means of production if they are a source economic power that is inadmissible to transmit to private hands, without risking to endanger general welfare" (Grigulevich, 2003, p. 328). Thus notes that any pattern of ownership has to bring the economic goods to all people. The same understanding of property is inherent in other world religions.

Outstanding representatives of the Russian Orthodox philosophy allocate in property some more essential properties.

They, first, proclaimed priority in property not its material, but its spiritual party. "A problem of a private property, I.A. Ilyin emphasizes, - is brought together to such understanding to a question, whether it befits to have to this creative spiritual center on the earth the certain strong, material nest provided to it and provided behind it - a nest of his life, his love, a child-bearing, work and a free initiative?" (Priests \& Shmelyov, 1991, p. 274). The possibility of creation of such material "nest" for the manifestation of human love and virtue it has to be provided to everyone and the state has to preserve it strictly. Such "nest" can expand both in collective, and in the national economy, and all this economic system has to have reliable protection.

They state, secondly, that work and property are continuous that "work, them making" is recognized as the basis of property (Solovyov, 1988, p. 433). V. S. Solovyov proclaimed illegal the property received by military capture, nationalization, privatization and other unearned, unjust way. In this divine world order, he wrote, there is only one exception - the right of hereditary property. It is necessary for preserving of a succession of the management of production as an essential condition of economic development. However, the law of succession should not generate the social group conducting a mainly parasitic way of life due to the inherited wealth.

The Russian religious philosophers, thirdly, focus attention that a source of the property is not so much work, how much material from which the consumer goods are made. That only use of the objective laws inherent in an object of the labor allows the person to make its transformations successfully. The property has to enrich, but not impoverish the surrounding nature. In addition, the creation of each new subject, as well as all the second, artificial life, has to bring the benefit of space and social environment, in God's trade.

The relations of an exchange of activity are the relations generated by public labor division. The secular political economy allocates in this sphere of economy an exchange of activities for "vertical" - between work managerial and work executive (work intellectual and physical) and on "horizontal" - between different producers of products. The religion considers such division reasonable, however not complete. In the field of an exchange of activity, it allocates as its primary ontological, transcendental aspect. The world develops according to the program set by the Creator. A task of the person to comprehend the logic of its development and to occupy the corresponding niche in space labor division. In the Universe one Subject of Management - God. Its "Constitution" has direct action. All people, whatever place they took in the system of a social production, have to follow his Pleasure first of all. All economic regulations that are not corresponding to the foreordained logic of the development of the world have to be brought into accord with it at all levels and on all links of a social production. This requirement was trampled by people on ignorance or sinfulness. They until now try to subordinate evolution of the world to the carnal, egotistical interests.

The relations of an exchange of activity include, secondly, an exchange of activity between managerial (intellectual) and executive (physical) work in society. Department of mental work from the physical was essential 
premises of economic and all social progress. It led to the creation of large-scale irrigational constructions, to sharp raising of the standard of farming, craft, trade, to the transformation of tribes to nationalities, to blossoming of arts and forming of science. The management of production objectively passed from society to theirs most prepared elite. Under laws of God public elite have to use the power in the world and happiness of all people, for the benefit of each person. However, the managerial tribe violated the Scripture and created antagonistic exploiter society.

It would be however wrong to blame for it only ruling classes, theologians learn. After Adam and Eve's fall, Blessed Augustine wrote, all people appeared in slavery at the lust, all of them the passion to wealth, the power and pleasures seized. Moreover, while all people, with rare exception, were that, individual and group egoism was the main incentive for the development of the public economy. Replacement of people at fed the authorities of nothing the moneychanger: one group of egoists and ambitious only changed on the captain's bridge of the public ship on, in fact, it another. Therefore, Christ also said the well-known: "To God - Gods, to the Caesar - Caesarian". Also bequeathed to the people not to revolt, not to arrange senseless bloodsheds, and to master management science, spiritually to tower over the level of the dominating elite before to raise the claim to the power. Because, He spoke oppressed and operated, "if your righteousness does not exceed a righteousness of scribes and Pharisees, you will not enter the Kingdom of Heaven" (Mf. 5: 20).

Alienation from the people of functions of the management and property perverted the nature of work. It became for the person, neither pleasure nor the highest manifestation of its creative power, but the damnation extinguishing his creative talents. As a result, the person began to feel free only at the accomplishment of the animal functions, only at food, drink, sexual intercourse. At best being located at itself in the dwelling, decorating itself (K. Marx).

The religion purpose in economic area - return to the mass of capability to the management of production, systematic recovery of the former unity of the subject and object of management. This process has to begin with a primary cage of production - the enterprise. Its labor collective has to be not only object, but also subject of management. "... Production, - V. S. Solovyov wrote, - should not be made to the account of human dignity of producers, and any of them should not become only an instrument of production" (Solovyov, 1988, p. 71). It is necessary to fix the union of the capital and work; it is emphasized in documents of the Second cathedral of Vatican. "... It is necessary keeping the necessary unity of management and organize in the best way the active participation of all in the management of the enterprises" (Casanova, 1973, p. 330).

In the last decades, the Christian concept of relations of production everything was implemented into the production of the countries that left in leaders of world economic development more widely. In the mid-eighties "in Germany in all large companies, workers possess a half of places in Boards of Directors. In the USA ... The law on the enterprises adopted in the summer of 1990 provides that a half of members of Boards of Directors of the enterprises is elected directly from labor collective, and another half - from shareholders" (Priests \& Shmelyov, 1991, p. 18-19). The American experience of the last years shows that the companies that are in joint property of workers are economically more productive. "Experience of the similar enterprises convinces nearly 1000 American campaigns annually to change the structure of ownership of capital stock and to pass to the property of workers" (Simmons \& Merce, 1993, p. 285).

This positive tendency in the economy, its approach to Christian ideals, was noticed and supported by Vatican. In September, 1981 the father John Paul II called the states and businessmen for expansion of participation of workers in the management of the enterprises as to a basis of a new public consent between workers, managers and owners. "Each person, - he declared, - has the right to consider itself as the co-owner of a workbench behind whom it works together with others." It has to "share responsibility and creatively participate" in the management of economy (Simmons \& Merce 1993, p. 259).

Implementation of the Christian principles of an exchange of activity in the field of production is dictated by the course of global development of the modern economy. Their violation is fraught with very substantial adverse effects.

\section{Discussion and Conclusion Remarks}

The relations of distribution characterize methods of the order by the made products. They include distribution of subjects of both productions and private consumption. The church recognizes that a source of personal wealth there has to be work. However, since the formation of slaveholding society the property became the primary source of the richness of ruling classes. It generated the shouting luxury of the dominating minority on one social pole and poverty - on other. For the elimination of this worldly defect, it is necessary to lift a priority and payment of live work. The salary of each working has to provide it material prosperity and possibility of all-round cultural development. The majority of churches resolutely rejects the myth about inborn laziness and carelessness of the person. The religion reminds - the person forms a society. As the image and God's similarity, it allocated with abundant creative talents. Moreover, if these talents were not opened 
or suppressed, first of all society is guilty. The church long since is the defender poor and oppressed is engaged in multidimensional charity.

The economic doctrine of Christianity remains, however, not demanded by civil society. The economy of a modern society is in the positions of materialism and rationalism occupied in the XVIII century. Methodologically its lag is entirely explainable. In difference, we will put, from the quantum theory with its geometrical field and virtual particles the economic science relies on mainly material experimental resources. It does not get into information, the ideal basis of the universe. To it, S. N. Bulgakov notes, the terrestrial pragmatism is inherent.

The economist operates with physical items and processes. It fills the production plan with real people, means and objects of the labor, predicts, plans, adjusts their interaction for the purpose of obtaining maximum economic, i.e. besides material efficiency. The narrow pragmatism is inherent in the field of the economy in both the scientist, both the entrepreneur, and the simple worker. "Between scanty knowledge of the expert owner and scientific experience there is a huge quantitative difference thanks to distinction in methods, extensiveness, orderliness of experience, but the qualitative, essential difference is not present" (Bulgakov, 1990, p. 138). The Economist does not have business before that many invisible threads with all Universe, with its objective evolution, connect each subject of the nature, each atom. The creator of its concepts does not have a place. This view is quite understandable and perfectly harmless in the past, in the era of modern scientific and technological revolution is becoming a more significant impediment to economic and social progress of all.

The person, realizing it or not, the business activities joins in the objective evolution of the world. He creates the second nature in which realizes the programs, implements the interests. These programs can be in a conflict with the development program of the Universe, with her Logos. Moreover, then the artificial nature created by the person becomes for the Universe a foreign matter and as the foreign matter is eliminated together with his local creators. To leave this deadly position, S. N. Bulgakov writes, the humanity should realize, at last, that the world is dual: it is spiritual and material at the same time. Production, as well as all the activity, society has to merge both with spiritual, and with material structure and evolution of the world.

\section{References}

Parsons, T. (2000). Structure of social action. M.: Academic project. pp. 880.

Merton, R.K. (2006). Social theory and social structure. M.: AST, Khranitel. pp. 880.

Weber, M. (1990). Protestants ethics and spirit of capitalism/Weber of M. Chosen works. - M.: Progress. pp. 808.

Weber, M. (1994). Economic ethics of world religions/Weber of M. Favorites. The image of society. M.: Lawyer. pp. 704.

Berdyaev, N.A. (1989). Philosophy of freedom. The sense of creativity. M.: However. pp. 607.

Ilyin, I.A. (1993). Way to evidence. M.: Republic. pp. 431.

Berdyaev, N.A. (1993). About appointment of the person. - M.: Republic. pp. 383.

Solovyov, V.S. (1988). Justification of the Good. Moral Philosophy //Solovyov V.S. Soch.: in 2 t. T.1. M.: Misl, pp. 822.

Casanova, A. (1973). Second Vatican cathedral: criticism of ideology and practice of modern Catholicism. M.: Progress. pp. 371.

Grigulevich, I.R. (2003). Papacy. A century of XX. M.: The TERRA - Book club. pp. 368.

Priests, V.V. \& Shmelyov N.P. (1991). Better late than never//Ackland K. Effective economy. Swedish model. - M.: economy. pp. 350.

Simmons, D. \& Merce U. (1993). How to become the owner. The American experience of participation of workers in property and management. M.: Arguments and facts. pp. 304.

Bulgakov, S.N. (1990). Philosophy of the economy. M.: Science. pp. 412. 
ISSN 2039-2117 (online) ISSN 2039-9340 (print)
Mediterranean Journal of Social Sciences MCSER Publishing, Rome-Italy
Vol 6 No 3 S4 May 2015 